\title{
SCIENCE AND LITERATURE IN THE
}

NINETEENTH CENTURY 


\section{CONTEXT AND COMMENTARY}

Series Editor: ARTHUR POLLARD

Published Titles

J.A.V. Chapple

SCIENCE AND LITERATURE IN THE NINETEENTH CENTURY

Pamela Horn

LIFE AND LABOUR IN RURAL ENGLAND, 1760-1850

Elisabeth Jay

FAITH AND DOUBT IN VICTORIAN BRITAIN

Robin Headlam Wells

SHAKESPEARE, POLITICS AND THE STATE

Forthcoming Titles

Dominic Hibberd

THE FIRST WORLD WAR

Norman Page

THE THIRTIES

Stephen Prickett

ENGLAND AND THE FRENCH REVOLUTION

Roger Richardson

REVOLT AND RESTORATION IN THE

SEVENTEENTH CENTURY

Alan and Dorothy Shelston

THE INDUSTRIAL CITY 


\section{SCIENCE AND LITERATURE IN THE NINETEENTH CENTURY}

J.A.V Chapple

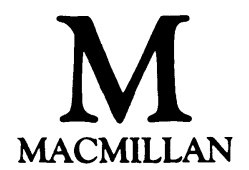


(C) J.A.V. Chapple 1986

All rights reserved. No reproduction, copy or transmission of this publication may be made without written permission.

No paragraph of this publication may be reproduced, copied or transmitted save with written permission or in accordance with the provisions of the Copyright Act 1956 (as amended).

Any person who does any unauthorised act in relation to this publication may be liable to criminal prosecution and civil claims for damages.

First published 1986

Published by

\section{MACMILLAN EDUCATION LTD}

Houndmills, Basingstoke, Hampshire RG21 2XS and London

Companies and representatives

throughout the world

Typeset by

Wessex Typesetters

(Division of The Eastern Press Ltd)

Frome, Somerset

British Library Cataloguing in Publication Data

Chapple, J.A.V.

Science and Literature in the Nineteenth Century

-(Context and commentary)

1. English literature-19th century-History

and criticism 2. Science in literature

I. Title

II. Series

$820.9^{\prime} 356$

PR468.S34

ISBN 978-0-333-37587-7 ISBN 978-1-349-18470-5 (eBook)

DOI 10.1007/978-1-349-18470-5 


\section{Contents}

Acknowledgements

List of Plates

Editor's Preface

vii

viii

ix

Introduction 1

Science and Sciences in the Nineteenth Century 1

Science in Culture 4

Science in Literature $\quad 12$

Cultural Exchange and Shared Discourse $\quad 15$

1. Astronomy, Physics, Chemistry, Meteorology 20

Unity in Diversity 20

The New Chemistry $\quad 25$

Meteorology and Natural Description $\quad 28$

Promethean Powers $\quad 33$

Science Fantasy $\quad 38$

Thermodynamics and the Promised End 43

The Scientific Love of Beauty 49

The Ultimate Realities $\quad 54$

2. Palaeontology, Geology, Zoology, Biology 58

A History of Extinctions $\quad 58$

Progressive Development $\quad 65$

Lamarckian Evolution $\quad 73$

Evolution by Natural Selection $\quad 79$

Evolution and Literature $\quad 83$

Evolution and Major Novelists $\quad 87$

Life in the Future $\quad 95$ 
vi Contents

3. Psychology, Anatomy, Physiology 99

Mind and Matter $\quad 99$

Strange Powers of Mind 101

The Body and Its Brain 108

Unconscious Cerebration 113

Evolutionary Psychology 116

4. Anthropology, Ethnology, Philology, Mythology 121

Race $\quad 121$

Races and Languages $\quad 125$

Evolutionary Anthropology 130

Mythology 135

Mythography, Ancient and Modern 139

5. Science and Literature 144

Early Nineteenth Century $\quad 144$

Later Nineteenth Century 150

A Modern Critical Approach 155

Chronological Table $\quad 163$

A Guide to Reading 182

Index 189 


\section{Acknowledgements}

I must thank the staff of the Brynmor Jones University Library at Hull and of the Cambridge University Library for all the help they have so professionally given me. I am also grateful to my colleagues and the University of Hull for a period of study leave during the 1984-85 session and, for a variety of help, to the following individuals: Gillian Beer, John Beer, Alan Bower, G.N. Cantor, John Christie, George Cole, Tess Cosslett, Gill Cowper, Ruth Green, Robin Headlam Wells, A.M. Hughes, Owen Knowles, Angela Leighton, Greg Myers, Marion Shaw, Sally Shuttleworth and Christopher Strachan. Some of this assistance was so informally sought that I make the usual statement of personal responsibility for all faults and errors with unusual emphasis. Yet again, I am pleased to acknowledge the constant encouragement and good advice of Arthur Pollard. James Chapple helped to compile the index. My deepest thanks must go to my wife, who in a world that seems to be ruled by John Herschel's 'law of higgledypiggledy', has done her best to make things what she would like them to be, Just So. 


\section{List of Plates}

1. Humphry Davy (1778-1829) in 1804.

Photograph (C) Royal Institution.

2. T.H. Huxley (1825-1895) lecturing in the early 1860 s. Photograph (C) Wellcome Institute Library, London.

3. Alfred Tennyson (1809-92) in c.1840 by S. Laurence. Photograph (C) National Portrait Gallery.

4. Charles Robert Darwin (1809-82), after the portrait by Maguire c. 1850.

Photograph (C) BBC Hulton Picture Library.

5. Faraday lecturing at the Royal Institution before the Prince Consort and the Prince of Wales. Photograph (C) Royal Institution.

6. How the elephant got its trunk as featured in the Just So Stories, 1902, by Rudyard Kipling (C) Bodleian Library, Oxford.

7. The frontispiece to T.H. Huxley's Evidence as to Man's place in Nature (1863) which shows four skeletons progressing from a gibbon to a man. 


\section{Editor's Preface}

J.H. Plumb has said that 'the aim of (the historian) is to understand men both as individuals and in their social relationships in time. "Social" embraces all of man's activities economic, religious, political, artistic, legal, military, scientific - everything, indeed, that affects the life of mankind.' Literature is itself similarly comprehensive. From Terence onwards writers have embraced his dictum that all things human are their concern.

It is the aim of this series to trace the interweavings of history and literature, to show by judicious quotation and commentary how those actually working within the various fields of human activity influenced and were influenced by those who were writing the novels, poems and plays within the several periods. An attempt has been made to show the special contribution that such writers make to the understanding of their times by virtue of their peculiar imaginative 'feel' for their subjects and the intensely personal angle from which they observe the historical phenomena that provide their inspiration and come within their creative vision. In its turn the historical evidence, besides and beyond its intrinsic importance, serves to 'place' the imaginative testimony of the writers.

The authors of the several volumes in this series have sought to intermingle history and literature in the conviction that the study of each is enhanced thereby. They have been free to adopt their own approach within the broad general pattern of the series. The topics themselves have sometimes also a particular slant and emphasis. Commentary, for instance, has had to be more detailed in some cases than in others. All the contributors to the series are at one, however, in the belief (at a time when some critics would not only divorce texts from their periods but even from their authors) that literature is the creation of actual men and women, actually living in an identifiable set of historical circumstances, themselves both the creatures and the creators of their times.

ARTHUR POLLARD 